\title{
Cell-Type-Specific Effects of Silibinin on Vitamin D-Induced Differentiation of Acute Myeloid Leukemia Cells Are Associated with Differential Modulation of RXR $\alpha$ Levels
}

\author{
Rina Wassermann, Victoria Novik, and Michael Danilenko \\ Department of Clinical Biochemistry, Faculty of Health Sciences, Ben-Gurion University of the Negev, P.O. Box 653, \\ 84105 Beer-Sheva, Israel \\ Correspondence should be addressed to Michael Danilenko, misha@bgu.ac.il
}

Received 26 February 2012; Accepted 15 March 2012

Academic Editor: George P. Studzinski

Copyright ( $) 2012$ Rina Wassermann et al. This is an open access article distributed under the Creative Commons Attribution License, which permits unrestricted use, distribution, and reproduction in any medium, provided the original work is properly cited.

Plant polyphenols have been shown to enhance the differentiation of acute myeloid leukemia (AML) cells induced by the hormonal form of vitamin $\mathrm{D}_{3}\left(1 \alpha, 25\right.$-dihydroxyvitamin $\left.\mathrm{D}_{3} ; 1,25 \mathrm{D}\right)$. However, how these agents modulate $1,25 \mathrm{D}$ effects in different subtypes of AML cells remains poorly understood. Here, we show that both carnosic acid (CA) and silibinin (SIL) synergistically enhancd 1,25D-induced differentiation of myeloblastic HL60 cells. However, in promonocytic U937 cells, only CA caused potentiation while SIL attenuated 1,25D effect. The enhanced effect of $1,25 \mathrm{D}+\mathrm{CA}$ was accompanied by increases in both the vitamin $\mathrm{D}$ receptor (VDR) and retinoid X receptor alpha $(\mathrm{RXR} \alpha)$ protein levels and vitamin $\mathrm{D}$ response element (VDRE) transactivation in both cell lines. Similar increases were observed in HL60 cells treated with 1,25D + SIL. In U937 cells, however, SIL inhibited 1,25Dinduced VDRE transactivation concomitant with downregulation of RXR $\alpha$ at both transcriptional and posttranscriptional levels. These inhibitory effects correlated with the inability of SIL, with or without $1,25 \mathrm{D}$, to activate the Nrf2/antioxidant response element signaling pathway in U937 cells. These results suggest that opposite effects of SIL on 1,25D-induced differentiation of HL60 and U937 cells may be determined by cell-type-specific signaling and transcriptional responses to this polyphenol resulting in differential modulation of RXR $\alpha$ expression.

\section{Introduction}

Acute myeloid leukemia (AML) is a hematologic cancer which results from blocked differentiation of hematopoietic stem and/or progenitor cells due to various genetic and epigenetic errors and is characterized by the uncontrolled proliferation of myeloid blasts. The standard approach for AML treatment is chemotherapy with cytarabine and anthracyclines; however, even after aggressive chemotherapy about $75 \%$ of AML patients relapse within 2 years of remission $[1,2]$. Recently, several targeted cytotoxic approaches to treat AML have been developed, for example, the use of kinase and histone deacetylase inhibitors [3], but such strategy is difficult to apply to AML, since the molecular lesions in AML are highly heterogeneous.
Differentiation therapy is an alternative or complementary treatment of AML which aims at inducing maturation of poorly differentiated leukemic blasts. The hormonal form of vitamin $\mathrm{D}_{3}\left(1 \alpha, 25\right.$-dihydroxyvitamin $\left.\mathrm{D}_{3}\right)$ is a strong differentiation inducer which has potential for the treatment of AML [4]. However, at concentrations capable of differentiating AML cells in culture 1,25D may cause fatal hypercalcemia in vivo. Many low-calcemic vitamin D analogs have been synthesized to date [5], but none has yet been shown to be appropriate for human use at concentrations required to induce differentiation of AML blasts. One way to overcome this problem is to combine low concentrations of $1,25 \mathrm{D}$ with other compounds which would enhance its anticancer, but not toxic, effects [6]. We have previously shown that carnosic acid (CA), the major phenolic diterpene 
of rosemary, potentiates the differentiation effects of $1,25 \mathrm{D}$ in AML cell lines representing different developmental blocks in myeloid differentiation, such as myeloblastic (HL60) [7-9], promye- locytic (NB4) [10], and (myelo)monocytic (U937, OCL- AML3, MOLM-13, THP-1) [9-12] leukemia cells, as well as in leukemic blasts derived from patients with AML [11]. Furthermore, combined treatments with either CA or CA-rich rosemary extract and different vitamin $\mathrm{D}$ derivatives resulted in enhanced differentiation and growth arrest of WEHI-3B D-murine myelomonocytic leukemia cells in vitro and-in case of rosemary extract-in cooperative antileukemic effects in syngeneic mouse AML models in vivo, without inducing hypercalcemia $[13,14]$. Another plant polyphenol, the flavonolignan silibinin (SIL) found in milk thistle, was also demonstrated to potentiate the differentiation effect of 1,25D in HL60 and OCL-AML3 cells $[7,12,15]$; however, this polyphenol tended to attenuate differentiation in U937 and THP-1 cells [16]. In addition, SIL exerted both potentiating and inhibitory effects on the differentiation of leukemic blast samples obtained from different patients with AML [17].

In this study we attempted to clarify the nature of the opposite effects of SIL on 1,25D-induced differentiation of HL60 and U937 cells using CA for comparison. We found that the differentiation-enhancing effect of the $1,25 \mathrm{D} / \mathrm{SIL}$ combination in HL60 cells was associated with upregulation of vitamin $\mathrm{D}$ receptor (VDR) and retinoid $\mathrm{X}$ receptor $(\mathrm{RXR} \alpha)$ levels compatible with increased transactivation of the vitamin D response element (VDRE). On the other hand, the inhibitory effect of SIL on 1,25D-induced differentiation of U937 cells was accompanied by downregulation of $\operatorname{RXR} \alpha$ expression and attenuated VDRE transactivation.

\section{Materials and Methods}

2.1. Chemicals, Antibodies, and Plasmids. Tissue culture media and reagents were from Invitrogen (Grand Island, NY), Biological Industries (Beit Ha'Emek, Israel), and HyClone (Logan, UT). Carnosic acid was purchased from Alexis Biochemicals (Läufenfingen, Switzerland). 1,25D was a gift from Dr. Andrzej Kutner (Pharmaceutical Research Institute, Warsaw, Poland). Silibinin, cycloheximide, tert-butylhydroquinone (tBHQ), and DMSO were from Sigma (Rehovot, Israel). Stock solutions of CA (10 mM), SIL (30 mM), 1,25D $(0.25 \mathrm{mM})$, and $\mathrm{tBHQ}(30 \mathrm{mM})$ were prepared in absolute ethanol. The precise concentrations of $1,25 \mathrm{D}$ in stock solutions were verified spectrophotometrically at $264 \mathrm{~nm}(\varepsilon=$ 19,000). The antibodies against NQO1 (C-19), VDR (C-20), RXR $\alpha$ (D-20), and TrxR1 (H-270) were from Santa Cruz Biotechnology Inc. (Santa Cruz, CA). Calreticulin antibody (PA3-900) was from Affinity BioReagents (Goden, CO). Peroxidase-conjugated donkey anti-rabbit and donkey antigoat IgG were from Jackson ImmunoResearch Laboratories Inc. (West Grove, PA). The 4xARE-Luc reporter construct containing four tandem repeats of the antioxidant response element (ARE) sequence from the glutathione S-transferase Ya subunit was a gift from Dr. M. Hannink (University of Missouri, Columbia, MO) [18]. The VDREx6-Luc reporter construct containing a 6-fold direct repeat 3 (DR3) sequence was kindly provided by Dr. L.P. Freedman (Memorial SloanKettering Cancer Center, New York, NY, USA). Renilla luciferase expression construct (pRL-null vector) was purchased from Promega (Madison, WI) and served as an internal transfection standard.

2.2. Cell Culture, Treatment, and Enumeration. HL60-G cells, subcloned from HL60 human myeloblastic leukemia cells [19], and U937 human myelomonocytic leukemia cells (American Type Culture Collection, Rockville, MD) were grown in RPMI 1640 medium supplemented with 10\% heatinactivated fetal calf serum or bovine serum in a humidified atmosphere of $95 \%$ air and $5 \% \mathrm{CO}_{2}$, at $37^{\circ} \mathrm{C}$. Cell cultures were passaged two to three times weekly to maintain a log phase growth. For experiments, cells were seeded in 6well plates (Greiner Bio-One GmbH, Solingen, Germany) at densities indicated in legends to figures followed by the addition of vehicle $(0.1 \%$ ethanol), 1,25D ( $1 \mathrm{nM})$, polyphenols, or their combinations under dim lighting conditions. Cell cultures were then incubated, as described above, for the indicated time periods. $1,25 \mathrm{D}$ alone at the higher concentration of $100 \mathrm{nM}$ was used as the positive control. Cell numbers and viability were estimated on the basis of trypan blue exclusion by counting in Vi-Cell XR cell viability analyzer (Beckman Coulter Inc., Fullerton, CA).

2.3. Determination of Markers of Differentiation. Aliquots of $1 \times 10^{6}$ cells were harvested, washed twice with phosphatebuffered saline (PBS), and suspended in $10 \mu \mathrm{L} 1 \times$ PBS. The cell suspensions were incubated for 45 minutes at room temperature with $0.3 \mu \mathrm{L}$ MO1-FITC and $0.3 \mu \mathrm{L}$ MY4-RD-1 to analyze the expression of the cell surface markers CD11b and CD14, respectively. The cells were then washed three times with ice-cold $1 \times \mathrm{PBS}$ and resuspended in $1 \mathrm{~mL}$ of PBS. Analysis was performed using Cytomics FC500 flow cytometer equipped with CXP software (Beckman Coulter). Isotypic mouse IgG1 was used to set threshold parameters.

2.4. Quantitative Reverse Transcription-Polymerase Chain Reaction ( $q R T-P C R)$. Total RNA was extracted from cells with the PerfectPure RNA Tissue Kit (5PRIME, Gaithers- burg, USA) and cDNA was prepared with Verso cDNA kit (ABgene, Epsom, UK), according to the manufacturer's instructions. The following primers were used for the determination of CD11b, CD14, and RXR $\alpha$ mRNA expression: CD11b, forward primer (5'-CTGTCTGCCAGAGAATCCAGTG-3'), reverse primer ( $5^{\prime}$-GAGGTGGTTATGCGAGGTCTTG-3'); CD14, forward primer (5'-GCCCTTACCAGCCTAGACCT$\left.3^{\prime}\right)$, reverse primer $\left(5^{\prime}\right.$-CCCGTCCAGTGTCAGGTTAT-3'); $\operatorname{RXR} \alpha$, forward primer ( $5^{\prime}$-CAAACATGGGGCTGAACC- $\left.3^{\prime}\right)$, reverse primer ( $5^{\prime}$-AAGTGTGGGATCCGCTTG-3'); ARP0, forward primer $\left(5^{\prime}\right.$-AGATGCAGCAGATCCGCAT- $\left.3^{\prime}\right)$, reverse primer ( $5^{\prime}$-GTGGTGATACCTAAAGCCTG-3'). cDNA samples $(7 \mu \mathrm{L})$ were diluted ninefold, mixed with the specific primers $(0.2 \mathrm{mM})$ and ABsolute Blue SYBR Green ROX Mix 
(ABgene, Epsom, UK) was then added to the reaction mixture. Reactions were carried out in the Rotor-Gene RealTime PCR machine (Corbett-Research, Northlake, Australia). Standard cycling conditions for this instrument were $15 \mathrm{~min}$ initial enzyme activation at $95^{\circ} \mathrm{C}$ then 35 cycles as follows: $10 \mathrm{sec}$ at $95^{\circ} \mathrm{C}, 15 \mathrm{sec}$ at the annealing temperature, and $15 \mathrm{sec}$ at $72^{\circ} \mathrm{C}$. The results were normalized by ARP0 mRNA content and quantified using the $2^{-\Delta \Delta \mathrm{C}_{\mathrm{T}}}$ method.

2.5. Preparation of Whole Cell Extracts and Western Blot Analysis. Cells were lysed in ice-cold lysis buffer containing $50 \mathrm{mM}$, HEPES (pH 7.5), $150 \mathrm{mM} \mathrm{NaCl}, 10 \%$ (v/v) glycerol, $1 \%(\mathrm{v} / \mathrm{v})$ Triton X-100, $1.5 \mathrm{mM}$ EGTA, $2 \mathrm{mM}$ sodium orthovanadate, $20 \mathrm{mM}$ sodium pyrophosphate, $50 \mathrm{mM} \mathrm{NaF}$, $1 \mathrm{mM}$ DTT, and 1:50 Complete Protease Inhibitors Cocktail (Roche Molecular Biochemicals, Mannheim, Germany) and centrifuged at 20,000 $\times g, 10 \mathrm{~min}, 4^{\circ} \mathrm{C}$. Supernatant samples (30 $\mu \mathrm{g}$ protein) were subjected to SDS-PAGE and then electroblotted into nitrocellulose membrane (Whatman, Dassel, Germany). The membranes were blocked with $5 \%$ milk for $2 \mathrm{~h}$ and incubated with primary antibodies overnight at $4^{\circ} \mathrm{C}$ followed by incubation with HRP-conjugated secondary antibodies for $2 \mathrm{~h}$. The protein bands were visualized using the Western Lightning Chemiluminescence Reagent Plus (PerkinElmer Life Sciences, Inc., Boston, MA). The blots were stripped and reprobed for the constitutively present protein, calreticulin, which served as the loading control. The optical density (OD) of protein bands was quantitated using Image Gauge 3.11 software (Fuji Photo Film Co., Tokyo, Japan). OD values for each protein were normalized to calreticulin and are displayed beneath each protein band.

2.6. Transient Transfection and Reporter Gene Assay. HL60 cells were transiently cotransfected with $4 x A R E-l u c$ reporter plasmid $(1.35 \mu \mathrm{g})$ and Renilla luciferase vector $(0.15 \mu \mathrm{g})$ or VDREx6-luc reporter plasmid $(0.95 \mu \mathrm{g})$ and Renilla luciferase vector $(0.05 \mu \mathrm{g})$ using Microporator (Digital Bio Technology, Seoul, Korea) under the following conditions: 1 pulse, 1400 Volts, pulse width $30 \mathrm{msec}$. U937 cells were transiently cotransfected with 4xARE-luc or VDREx6-luc reporter plasmids $(0.8 \mu \mathrm{g})$ and Renilla luciferase vector $(0.2 \mu \mathrm{g})$ using JetPEI Reagent (POLYplus-Transfection, Illkirch Cedex, France), according to the manufacturer's instructions. Transfected cells were exposed to the indicated treatments for $24 \mathrm{~h}$ followed by measurement of luciferase activity using the Dual Luciferase Reporter Assay system (Promega, Medison, WI, USA). The data are presented as the normalized ratios of firefly luciferase to Renilla luciferase activity (relative luminescence units, RLU).

2.7. Statistical Analysis. The significance of the differences between the means of the various subgroups was assessed by unpaired two-tailed Student's $t$-test. Two compounds ( $A$ and $B$ ) were considered to show enhancement in the particular experiment if the effect of their combination $(A B)$ was larger than the sum of their individual effects $(A B>A+B)$, the data being compared after subtraction of the respective control values from $A, B$, and $A B[8]$. The statistical analysis was performed with the GraphPad Prism 5.0 Program (GraphPad Software, San Diego, CA). Data are presented as the mean \pm SE. $P<0.05$ was considered statistically significant.

\section{Results}

3.1. Silibinin Potentiates 1,25D-Induced Differentiation in HL60 Cells While Attenuating It in U937 Cells. We first compared the effects of CA and SIL on the expression of two cell surface markers of myeloid differentiation, CD11b and CD14, induced by a low concentration of 1,25D ( $1 \mathrm{nM})$ in HL60 and U937 cells (Figure 1). To exclude potential interference of reagent cytotoxicity in the determination of the vitamin $\mathrm{D}$ receptor expression and activity, as described in the following sections, we used noncytotoxic concentrations of the two polyphenols: $10 \mu \mathrm{M}$ CA for both cell lines [7, 8, 20], $60 \mu \mathrm{M}$ SIL for HL60 cells [7, 16, 17, 20], and $30 \mu \mathrm{M}$ SIL for U937 cells. Under these conditions, cell viability was maintained at 95-98\% throughout the course of the experiments performed here. Concentrations of SIL higher than $30 \mu \mathrm{M}$ caused a dose-dependent decrease in the viability of U937 cells (up to $\sim 20 \%$ dead cells at $60 \mu \mathrm{M}$ SIL; data not shown). The addition of CA to $1,25 \mathrm{D}$ not only synergistically increased the percentage of CD11b- and CD14-positive HL60 and U937 cells, as measured by flow cytometry following $96 \mathrm{~h}$ treatment (Figures 1(a), 1(b)), but also markedly enhanced the mRNA expression of these markers after $24 \mathrm{~h}$ (Figures 1(c), 1(d), 1(e), and 1(f)), as compared to $1,25 \mathrm{D}$ alone. These potentiating effects of CA were more pronounced in HL60 cells than in U937 cells. On the other hand, while being even a stronger differentiation enhancer than CA in HL60 cells (Figures 1(a),1(c), and 1(d)), SIL appreciably reduced 1,25D-stimulated expression of CD11b and CD14 in U937 cell, as determined by both flow cytometry (Figure 1(b)) and qRT-PCR (Figures 1(e), 1(f)).

3.2. Silibinin Cooperates with 1,25D to Induce Growth Arrest in HL60 Cells but Not in U937 Cells. In parallel with flow cytometric determination of CD11b and CD14 expression (Figures 1(a) and 1(b)), cells from the same wells were enumerated to examine the effects of 1,25D and polyphenols on cell proliferation and viability. As shown in Figure 2(a), both CA and SIL administered alone for $96 \mathrm{~h}$ significantly decreased the number of proliferating HL60 cells while $1 \mathrm{nM}$ $1,25 \mathrm{D}$ alone had a minor effect. However, the addition of $1,25 \mathrm{D}$ to either of the two polyphenols resulted in a marked cooperative inhibition of cell growth comparable to that produced by high-dose 1,25D (100 nM). U937 cells exhibited lower sensitivity to the antiproliferative effect of $1,25 \mathrm{D}$, as compared to HL60 cells. CA produced similar effects in both cell lines, whereas SIL caused somewhat stronger growth inhibition in U937 even at a 2-fold lower concentration than used in HL60 cells (Figure 2(b) versus Figure 2(a)). Interestingly, while treatment with the 1,25D/CA combination resulted in a more pronounced reduction in U937 cell numbers than that exerted by single compounds, the antiproliferative effect of SIL was not significantly altered by 

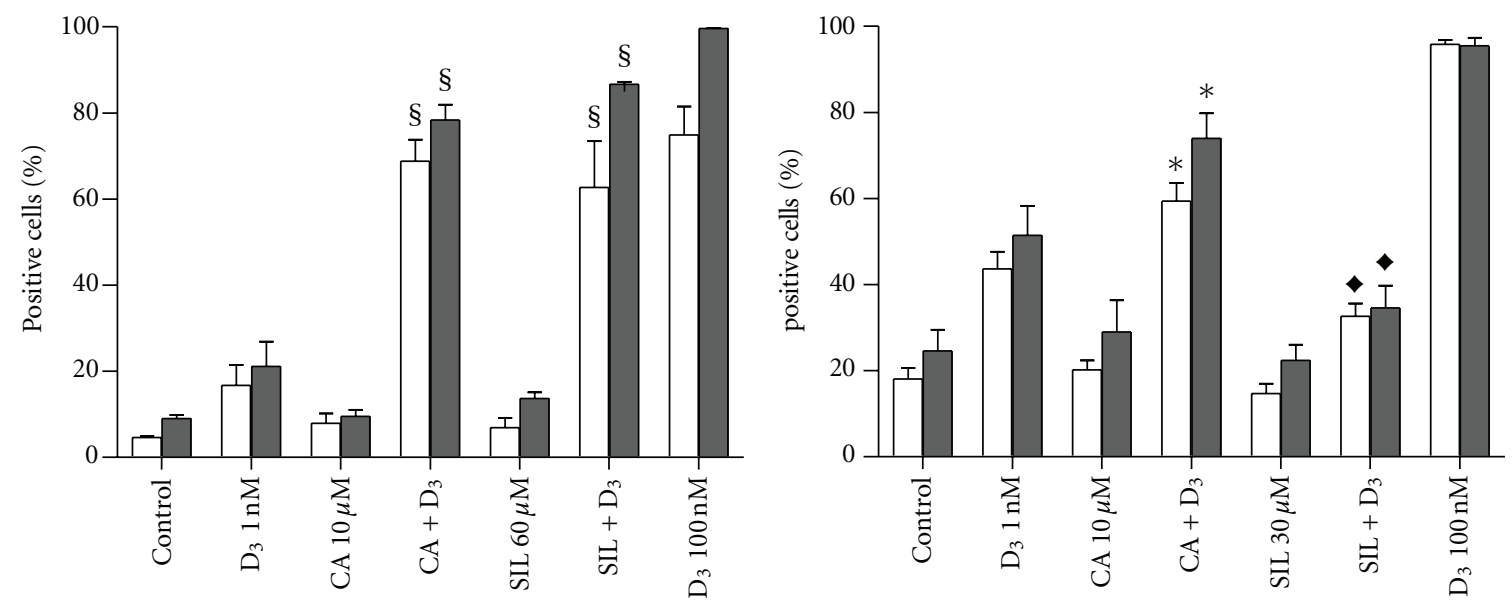

(a) HL60

(b) U937

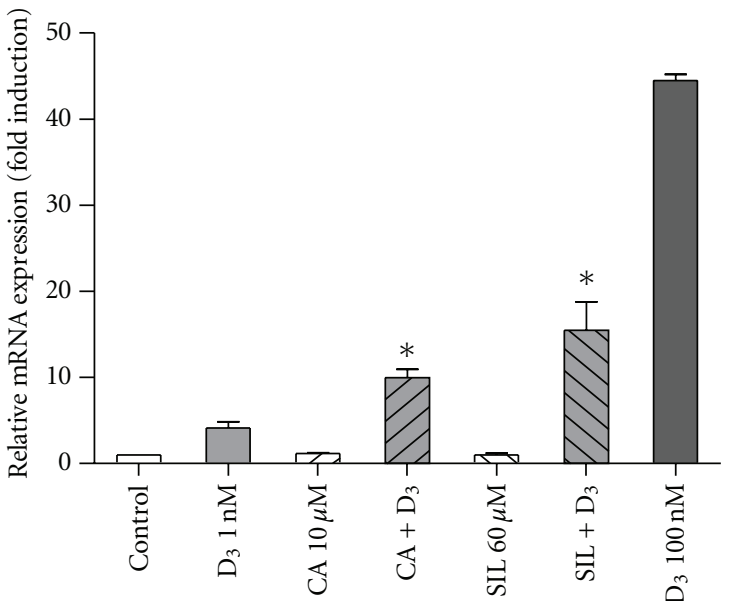

(c) HL60 - CD11b

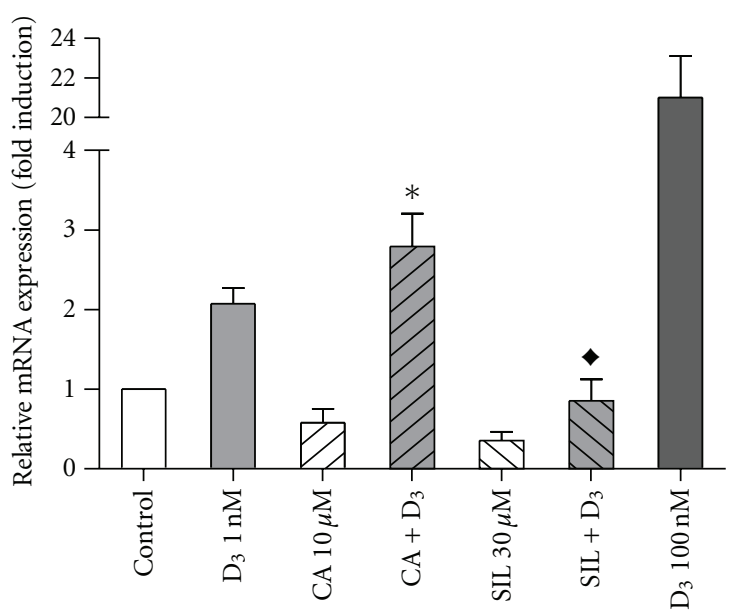

(e) $\mathrm{U} 937-\mathrm{CD} 11 \mathrm{~b}$

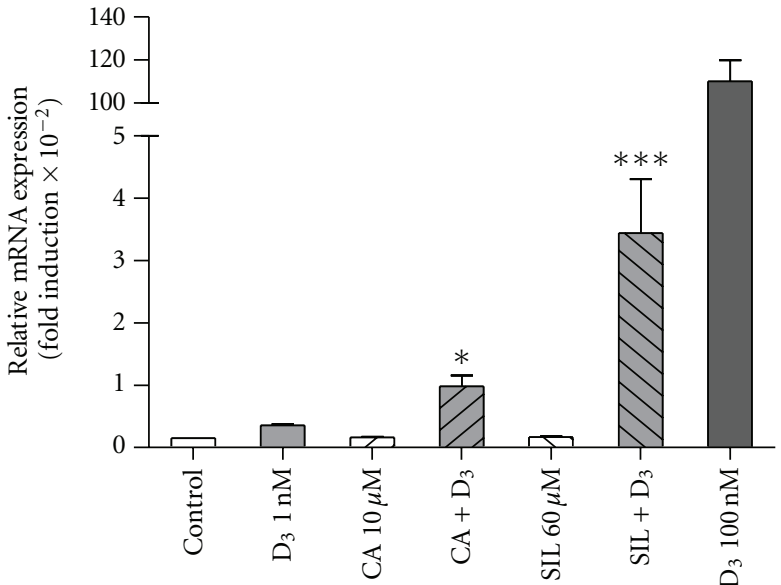

(d) HL60 - CD14

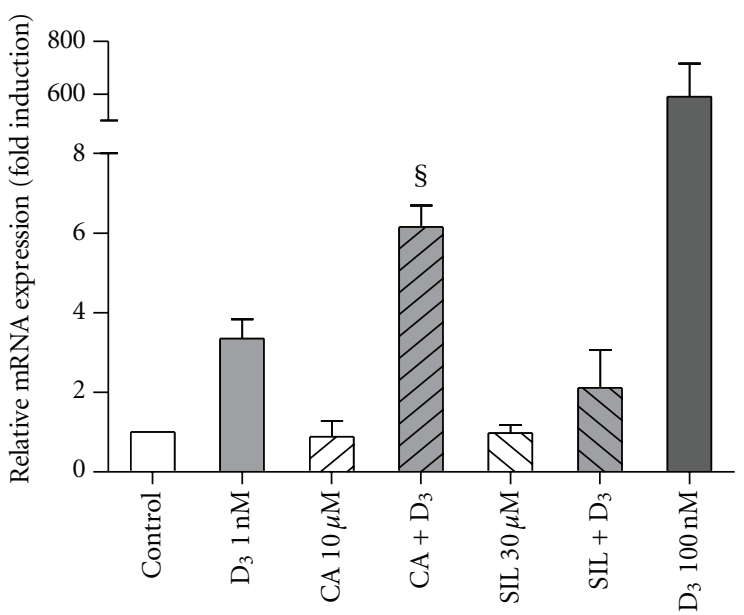

(f) $\mathrm{U} 937-\mathrm{CD} 14$

Figure 1: Carnosic acid enhances while silibinin differentially affects 1,25D-induced differentiation of HL60 and U937 cells. Cells were incubated at $4 \times 10^{4}$ cells $/ \mathrm{mL}$ (a), (b) or $5 \times 10^{4}$ cells $/ \mathrm{mL}(\mathrm{c}-\mathrm{f})$ with $0.1 \%$ ethanol (vehicle control) or the indicated test agents, alone or in combination, for $96 \mathrm{~h} \mathrm{(a),} \mathrm{(b)} \mathrm{or} 24 \mathrm{~h}$ (c-f). CD11b and CD14 expression was then determined by flow cytometry (a), (b) or qRT-PCR (c-f). The data are the means \pm SE of 5 (a), (b) or 3 (c-f) independent experiments. ${ }^{*} P<0.05$; ${ }^{\S} P<0.01$, or $* * * P<0.001$, combination $v e r s u s$ sum of single agents for enhancing effects. $P<0.05$, combination versus $1 \mathrm{nM} 1,25 \mathrm{D}$ alone for inhibitory effects. 


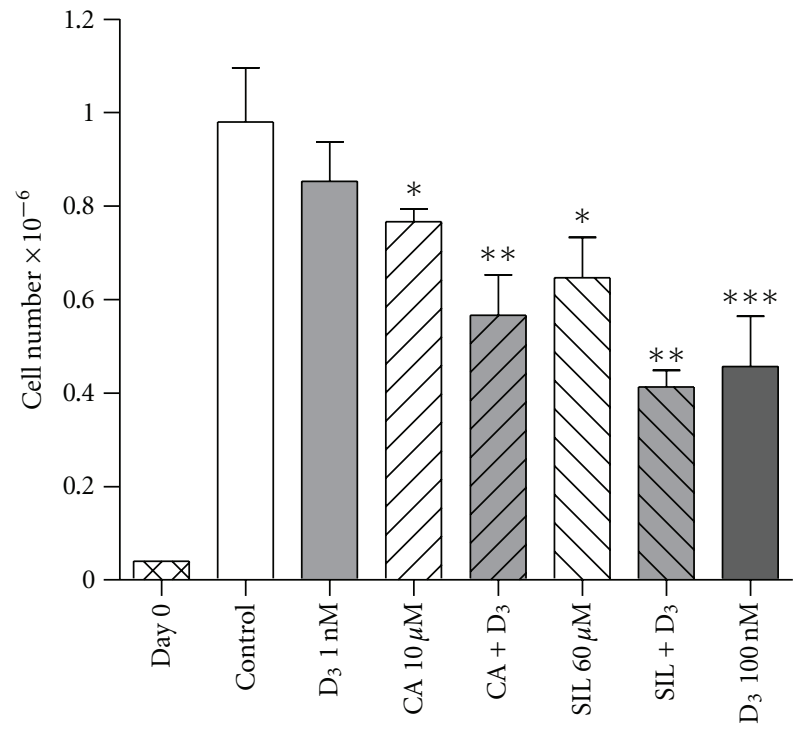

(a) HL60

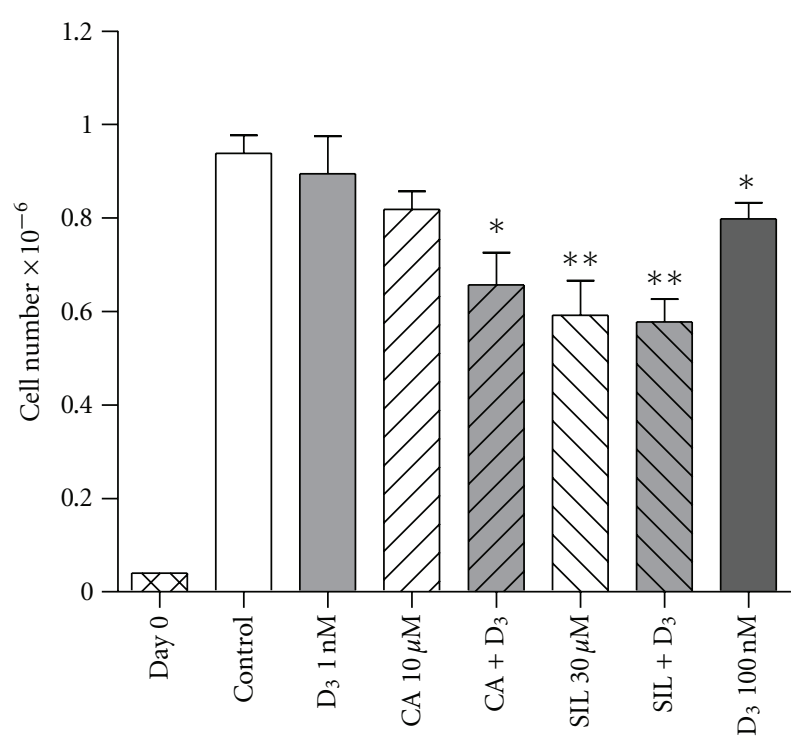

(b) U937

FIGURE 2: Carnosic acid and silibinin, alone and in combination with 1,25D, inhibit proliferation of HL60 and U937 cells. Cells were seeded at $4 \times 10^{4}$ cells/mL (day 0 ) and treated with test agents, for $96 \mathrm{~h}$, as described in legend to Figure 1 . Following incubation, cells were counted using the trypan blue exclusion assay. The numbers of viable cells are presented as the means \pm SE of at least 5 independent experiments. ${ }^{*} P<0.05 ;{ }^{* *} P<0.01$, or ${ }^{* * *} P<0.001$, treatments versus control.

1,25D (Figure 2(b)). In the previous experiments, no treatment tested significantly affected cell viability $(93-96 \%$ in all samples). These findings are consistent with our previous data showing antiproliferative effects of CA and SIL, alone and in combination with different vitamin $\mathrm{D}$ derivatives, in murine and human AML cell lines $[8,9,13,14,20,21]$.

\subsection{Silibinin Potentiates 1,25D-Induced VDRE Transactiva-} tion in HL60 Cells While Inhibiting It in U937 Cells: Association with RXR $\alpha$ Protein Levels. To examine the mechanism underlying the differential effects of SIL on 1,25D-induced differentiation in HL60 and U937 cells we tested the hypothesis that, similar to CA, SIL promotes the functional activation of the vitamin D receptor by 1,25D in HL60 cells while, in contrast to CA, attenuating it in U937 cells. To this end, we first compared the effects of CA and SIL on $1 \mathrm{nM} 1,25 \mathrm{D}$ induced VDRE transactivation in transiently transfected HL60 and U937 cells using VDRE-Luc reporter gene assay. As expected, both CA and SIL markedly enhanced 1,25Dstimulated transcription from VDRE in HL60 cells (Figure $3(a))$. A similar potentiating effect of CA was observed in U937 cells; however, SIL significantly reduced VDRE transactivation by $1,25 \mathrm{D}$ in this cell line (Figure $3(\mathrm{~b})$ ). The above differential effects of CA and SIL on VDRE activation correlated with their corresponding modulation of 1,25Dinduced differentiation in the two cell lines (see Figure 1).

We then performed Western blot analysis of VDR and RXR $\alpha$ protein expression in untransfected HL60 and U937 cells following incubations with $1,25 \mathrm{D}$, polyphenols, and their combinations for $48 \mathrm{~h}$ and $96 \mathrm{~h}$. The data demonstrated that $1,25 \mathrm{D}$ alone induced a dose- and time-dependent elevation of VDR levels in both HL60 and U937 cells (Figures 4(a-d)) and of RXR $\alpha$ levels in HL60 cells (Figures 4(a) and 4(b)). When added alone, CA and SIL caused only modest increases in VDR levels in both cell lines but cooperated with $1 \mathrm{nM} 1,25 \mathrm{D}$ in this effect. This cooperative VDR upregulation tended to strengthen with time and was much stronger in HL60 cells than in U937 cells (compare panels (a), (b) and (c), (d) in Figure 4). A similar, though less pronounced, positive cooperation between both polyphenols and 1,25D was also observed for RXR $\alpha$ levels in HL60 cells. However, in U937 cells, only CA, alone or in combination with 1,25D, positively affected RXR $\alpha$ expression. In contrast, treatment with SIL or $1,25 \mathrm{D}$ alone tended to decrease $\operatorname{RXR} \alpha$ levels with time (Figures 4(c) and 4(d)) and their combination caused a marked time-dependent RXR $\alpha$ downregulation in these cells (Figures 4(c) and 4(d)). The latter inhibitory effect may, at least in part, account for the attenuated VDRE transactivation observed in 1,25D/SIL-treated U937 cells (Figure 3(b)).

3.4. Silibinin in Combination with 1,25D Downregulates RXR $\alpha m R N A$ Expression and Decreases RXR $\alpha$ Protein Stability in U937 Cells. To determine the mode by which treatments with SIL and its combination with $1,25 \mathrm{D}$ reduce RXR $\alpha$ protein levels in U937 cells, we first compared the effects of SIL, CA, 1,25D, alone and together, on RXR $\alpha$ mRNA expression in both HL60 and U937 cells. As shown in Figure 6(a), neither treatment significantly affected RXR $\alpha$ mRNA levels in HL60 cells following 24-h incubations. A similar pattern was observed in U937 cells for all of the treatments except for the 1,25D/SIL combination which markedly 


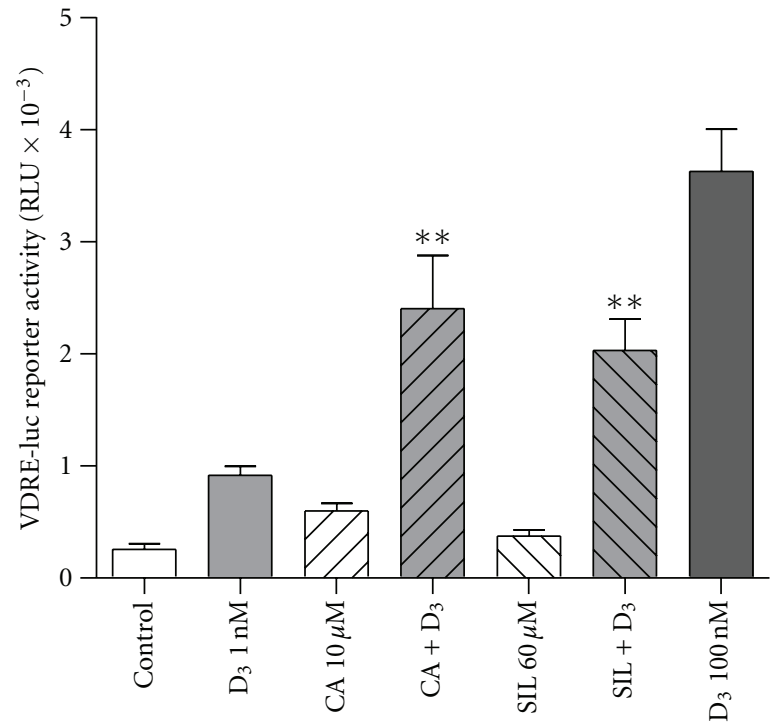

(a) HL60

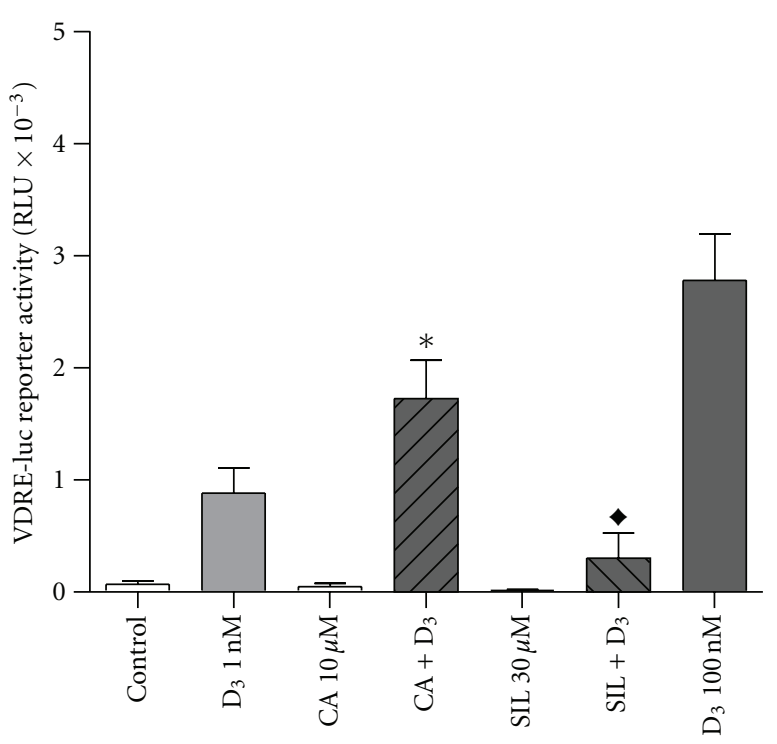

(b) U937

FIGURE 3: Carnosic acid enhances while silibinin differentially affects 1,25D-induced VDRE transactivation in HL60 and U937 cells. Cells $\left(5 \times 10^{5}\right.$ cells $\left./ \mathrm{ml}\right)$ were transiently transfected with VDRE $\times 6$-luc and Renilla luciferase reporter constructs followed by treatment with $0.1 \%$ ethanol (control) or indicated test agents for $24 \mathrm{~h}$. The relative VDREx6-luc activity (means \pm SE) was calculated from the data of 3 individual experiments performed in triplicate. ${ }^{*} P<0.05$ and ${ }^{* *} P<0.01$, combination versus sum of single agents for enhancing effects.

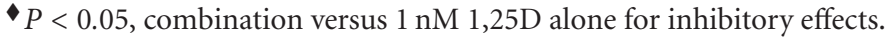

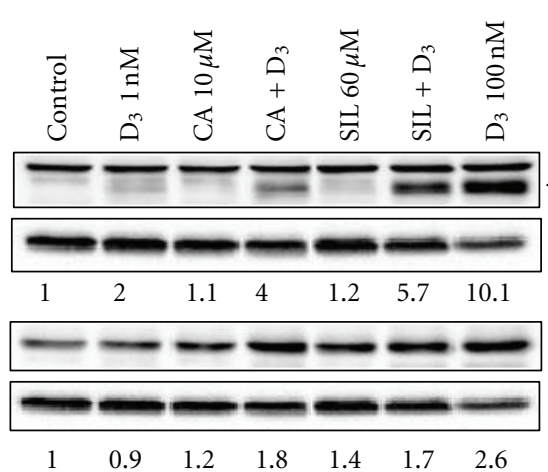

(a) HL60 (48 h)

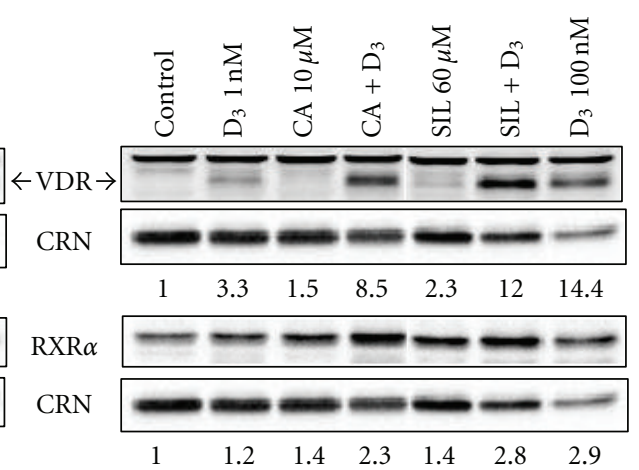

(b) HL60 (96 h)

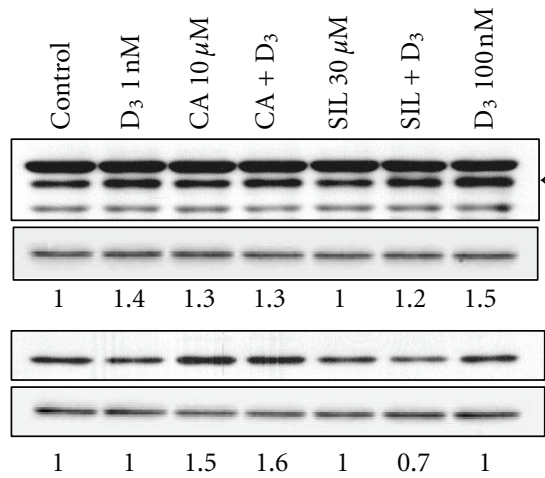

(c) U937 (48 h)

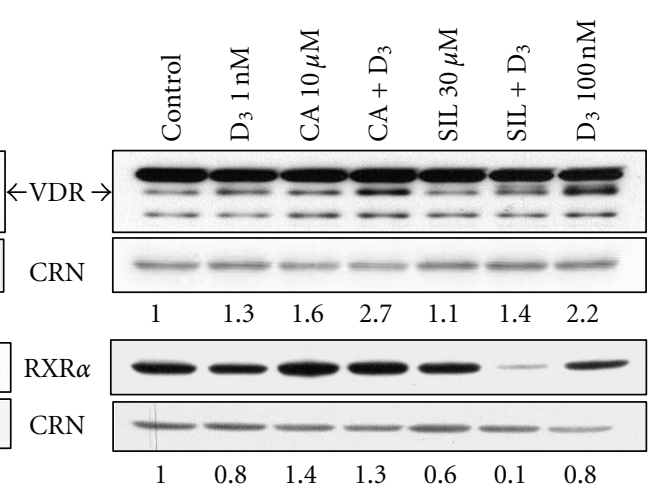

(d) U937 (96 h)

FIGURE 4: Effects of 1,25D, carnosic acid and silibinin, alone and in combination, on VDR and RXR $\alpha$ protein expression in HL60 and U937 cells. Cells were treated for $48 \mathrm{~h}\left(1 \times 10^{5}\right.$ cells $/ \mathrm{mL}$; (a), (c) $)$ or $96 \mathrm{~h}\left(4 \times 10^{4} \mathrm{cells} / \mathrm{mL}\right.$; (b), (d)) with $0.1 \%$ ethanol (control) or the indicated test agents. Protein expression was then determined by Western blotting. Calreticulin (CRN) was used as the protein loading control. Representative blots of at least 3 independent experiments are shown. 
lowered RXR $\alpha$ mRNA expression levels compared to either untreated cells or treatments with single agents. The latter effect correlated with a strong reduction in $\operatorname{RXR} \alpha$ protein levels following 1,25D/SIL treatment (e.g., Figure 4(d)). To examine if this reduction can also result from a decrease in $\operatorname{RXR} \alpha$ protein stability, we performed cycloheximide chase experiments. U937 cells were preincubated for 24$72 \mathrm{~h}$ with or without SIL or SIL $+1,25 \mathrm{D}$, washed, and exposed to $400 \mu \mathrm{M}$ cycloheximide [22] to block protein synthesis. The time course of RXR $\alpha$ protein degradation in different samples was then followed for up to $8 \mathrm{~h}$ by Western blot analysis of relative protein levels. Cycloheximide did not significantly affect cell viability during the treatment. Interestingly, as shown in Figures 6(c) and 6(d), higher rates of reduction in RXR $\alpha$ levels were obtained in cells pretreated for $72 \mathrm{~h}$ with SIL alone (Figure 6(c), lanes 79) and, particularly, in combination with 1,25D (Figure 6(c), lanes 10-12), as compared to control cells (Figure 6(c), lanes 4-6). However, shorter preincubations revealed either less pronounced $(48 \mathrm{~h})$ or no $(24 \mathrm{~h})$ appreciable effects of SIL or SIL $+1,25 \mathrm{D}$ on $\mathrm{RXR} \alpha$ degradation rates in the presence of cycloheximide (data not shown). Therefore, it appears that the time-dependent reduction in $\mathrm{RXR} \alpha$ protein levels following treatment of U937 cells with SIL and, especially, its combination with $1,25 \mathrm{D}$ (Figures $4(\mathrm{c})$ and $4(\mathrm{~d})$ ), may result from both the earlier inhibition of mRNA expression (Figure 6(b)) and later decrease in protein stability (Figures 6(c) and 6(d)).

3.5. Silibinin Activates the Nrf2/Antioxidant Response Element (Nrf2/ARE) Signaling Pathway in HL60 Cells but Not in U937 Cells. Our recent data have demonstrated that CA and 1,25D can synergistically activate the Nrf2/ARE signaling pathway and that Nrf2 acts as an upstream positive regulator of VDR and RXR $\alpha$ expression in U937 cells [11]. We, thus, determined whether SIL, alone or together with $1,25 \mathrm{D}$, is capable of activating this pathway in HL60 and U937 cells, as compared with $C A \pm 1,25 \mathrm{D}$. Using ARE-Luc reporter gene assays in transiently transfected cells, we found that both CA and, to a lesser extent, SIL induced ARE transactivation in HL60 cells and that the addition of $1 \mathrm{nM} 1,25 \mathrm{D}$, which alone had only a slight effect, synergistically potentiated the effects of the two polyphenols (Figure 5(a)). Likewise, both CA and SIL as well as 1,25D/CA and 1,25D/SIL combinations induced the expression of the Nrf2/ARE-responsive gene products, $\mathrm{NAD}(\mathrm{P}) \mathrm{H}$ quinone oxidoreductase-1 (NQO1) and thioredoxin reductase-1 (TrxR1), in these cells to different extent (Figure 5(c)). On the other hand, only CA, alone or together with $1,25 \mathrm{D}$, was capable of trasactivating the ARE reporter (Figure 5(b)) and inducing NQO1 and TrxR1 expression, whereas SIL $\pm 1,25 \mathrm{D}$ even tended to decrease the levels of these proteins (Figure 5(d)).

\section{Discussion}

In this study we characterized the distinct modulatory effects of SIL on myeloid differentiation of HL60 and U937 human AML cells induced by a low, near physiologic concentration of 1,25D. For comparison, we utilized another plant polyphenol, CA, which differentiation-enhancing activity has been consistently demonstrated in both cell lines $[7-9,11,20]$. SIL had also been first described as phytochemical which can synergistically potentiate 1,25D-induced differentiation of HL60 myeloblastic leukemia cells [15] and this finding was later confirmed in our studies [7, 20]. However, when testing the promonocytic leukemia cell lines U937 and THP1 , which can also be induced to differentiate by $1,25 \mathrm{D}$, we observed a surprising inhibition of the 1,25D effect by this polyphenol ([16] and this study). This inhibition seems to be a rather unusual phenomenon in view of a number of reports consistently showing differentiation-enhancing activity of various plant-derived bioactive compounds. Among these are different polyphenols (besides CA and SIL) [7, 24-26], sesquiterpene lactones [27-29], carotenoids [30, 31], and other phytochemicals, such as genistein [32], capsaicin [33], or cotylenin A [34].

Mechanisms underlying the potentiating effects of the above compounds on 1,25D-induced differentiation of AML cells have been extensively studied and shown to involve the activation of various signaling kinases, such as protein kinase C [15, 28, 29], phosphatidylinositol 3-kinase [28]; MAPKs, including ERK [7, 15, 28, 29] and JNK [20], as well as the transcription factors AP-1 [7, 11, 20], Egr-1 [8, 20], and Nrf2 [11]. Furthermore, the differentiation-enhancing effects of some phytochemicals, for example, curcumin [24] and parthenolide [27], or unrelated antioxidants, for example, $\alpha$-tocopherol succinate [30], were associated with their inhibition of $\mathrm{NF} \kappa \mathrm{B}$, the transcription factor which has been reported to antagonize VDR-mediated 1,25D actions $[35,36]$.

Interestingly, activation of at least some of the above signaling and transcriptional pathways has been shown to promote VDR, and RXR $\alpha$ expression, which may eventually represent a major cause for the sensitization of cancer cells to lower doses of $1,25 \mathrm{D}$ in the presence of phytochemicals or other enhancers of 1,25D action. For instance, activation of the p38 and JNK MAPK pathways in breast cancer cells was found to increase VDR expression via upregulation of AP-1 which can bind to and transactivate the VDR gene promoter [37]. In addition, AP-1 was found to play an important role in regulation of $\mathrm{RXR} \alpha$ expression in osteoblastic cells [38]. Our recent study has demonstrated that in U937 cells the expression of AP-1, VDR, and RXR $\alpha$ can be controlled by Nrf2 activity [11]. Correspondingly, we have previously shown that the synergistic differentiation effects of $1,25 \mathrm{D}$ and CA in AML cells correlated with a marked cooperative increase in VDR and $\operatorname{RXR} \alpha$ levels $[8,11]$. A similar VDR protein upregulation in leukemia cells was observed when $1,25 \mathrm{D}$ was combined with other inducers or enhancers of differentiation, such as all trans retinoic acid (ATRA) [39] and bufalin [40], a major digoxin-like component of toad venom. Likewise, enhanced antiproliferative effects of $1,25 \mathrm{D}$ combinations with the soy isoflavone genistein [41-43] or the RRR stereoisomer of $\alpha$-tocopherol [44] in nonleukemic cancer cells were associated with elevated VDR expression.

In view of the above findings we hypothesized that the mechanism by which SIL attenuates 1,25D-induced 


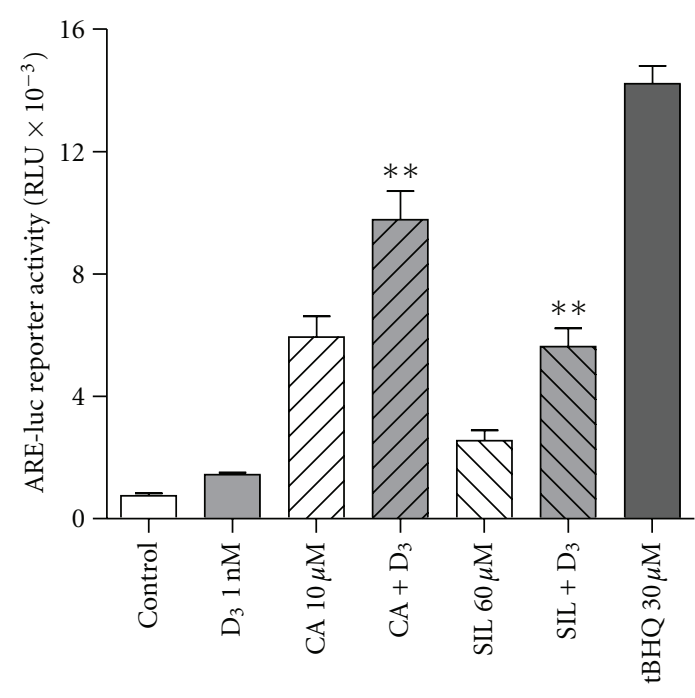

(a) HL60

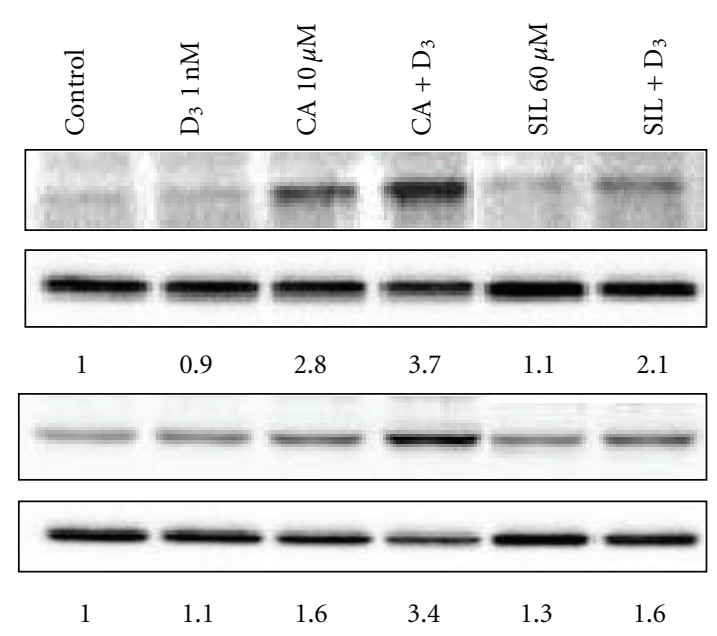

(c) HL60

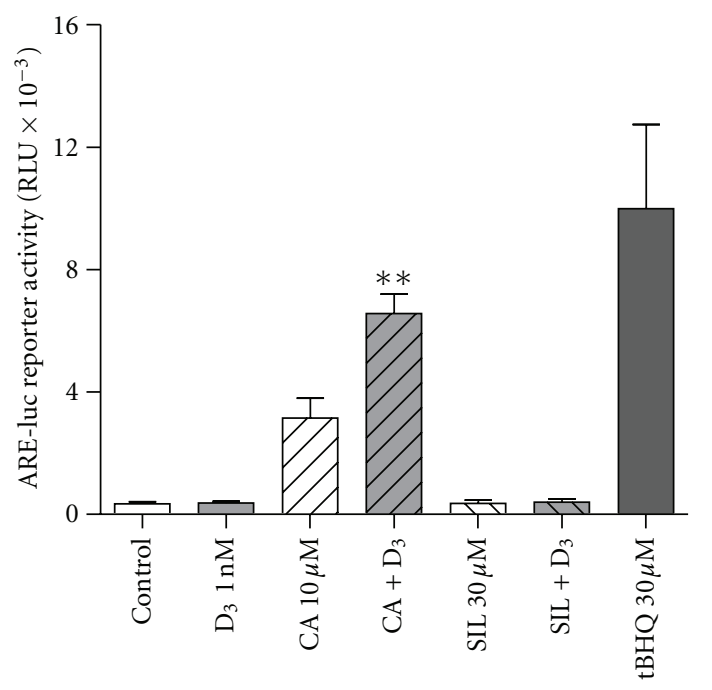

(b) U937

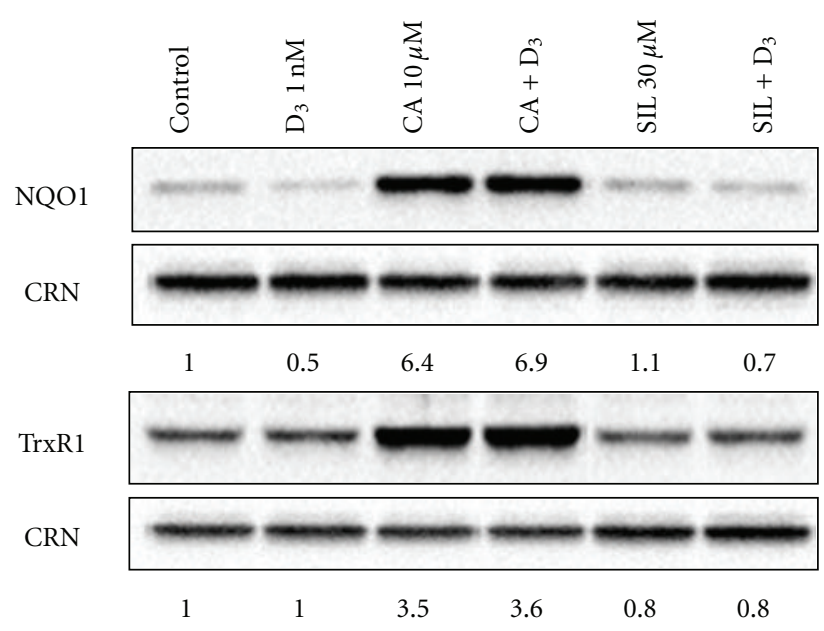

(d) U937

FIgURE 5: Effects of carnosic acid, silibinin, and 1,25D, alone and in combination, on the Nrf2/ARE signaling pathway in HL60 and U937 cells. (a), (b) Cells were transiently transfected with 4xARE-luc and Renilla luciferase reporter constructs followed by treatment with $0.1 \%$ ethanol (control) or indicated test agents for $24 \mathrm{~h}$. tert-Butylhydroquinone (tBHQ), a classical Nrf2/ARE activator [23], was used as the positive control. The relative $4 x$ ARE-luc activity (means \pm SE) was calculated from the data of 4 individual experiments performed in triplicate. ${ }^{* *} P<0.01$, combination versus sum of single agents. (c), (d) Cells $\left(1 \times 10^{5}\right.$ cells $/ \mathrm{mL}$ ) were treated with $0.1 \%$ ethanol (control) or the indicated test agents, for $48 \mathrm{~h}$. Protein expression was then determined by Western blotting. Calreticulin (CRN) was used as the protein loading control. Representative blots of at least 3 independent experiments are shown.

differentiation in U937 cells could result from a decrease in $\mathrm{VDR} / \mathrm{RXR} \alpha$ expression and/or activity. Indeed, we obtained several lines of evidence indicating a strong correlation between the attenuated response to 1,25D and reduced vitamin D receptor activity, namely, the SIL inhibition of 1,25D-induced VDRE transactivation that was consistent with a marked decrease in $\operatorname{RXR} \alpha$ expression levels and protein stability. Of note, SIL also inhibited ATRA-induced differentiation of U937 cells in our experiments (manuscript in preparation). Since the retinoic receptor alpha (RAR $\alpha$ ) heterodimerizes with $\mathrm{RXR} \alpha$ to produce a functionally active receptor for ATRA (e.g., [45]), these data suggest that RXR $\alpha$ can serve as a common target for the negative effect of SIL on maturation of these cells induced by both $1,25 \mathrm{D}$ and ATRA. Surprisingly, in contrast to HL60 cells, 1,25D itself tended to downregulate RXR $\alpha$ expression in U937 cells and, thus, the greatest reduction in RXR $\alpha$ levels was observed in cells treated with the $1,25 \mathrm{D} / \mathrm{SIL}$ combination. One possible explanation for the "anti-differentiation" behavior of SIL in these cells is that it may activate some differentiationantagonizing factor(s) and cooperate with 1,25D in this effect. Indeed, it has been shown that $1,25 \mathrm{D}$ and SIL can concurrently upregulate and activate ERK5 (big MAPK-1) and its upstream regulator, Cot1 kinase [16], which has a negative effect on 1,25D-induced differentiation of AML cells [46]. In addition, high expression levels of at least 


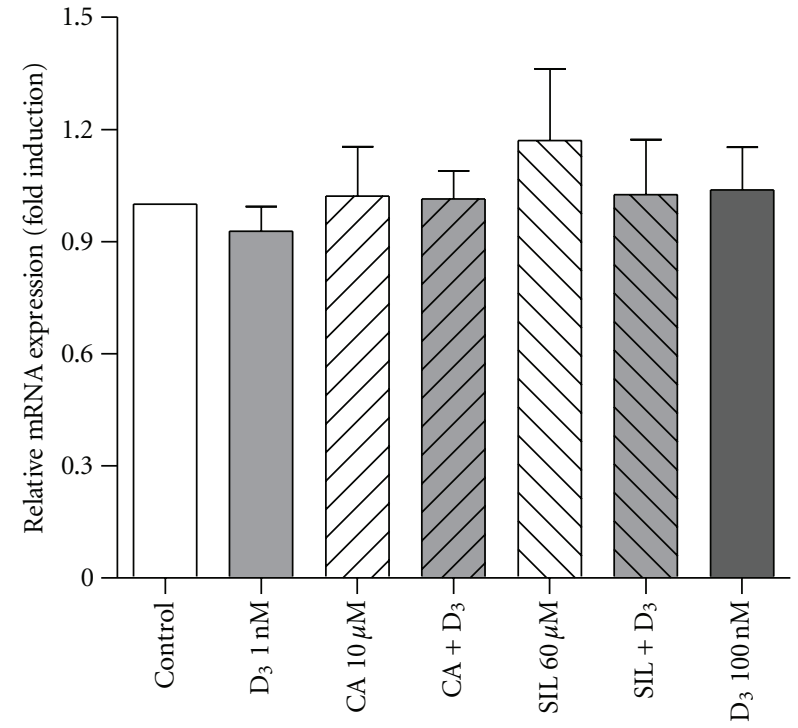

(a) HL60

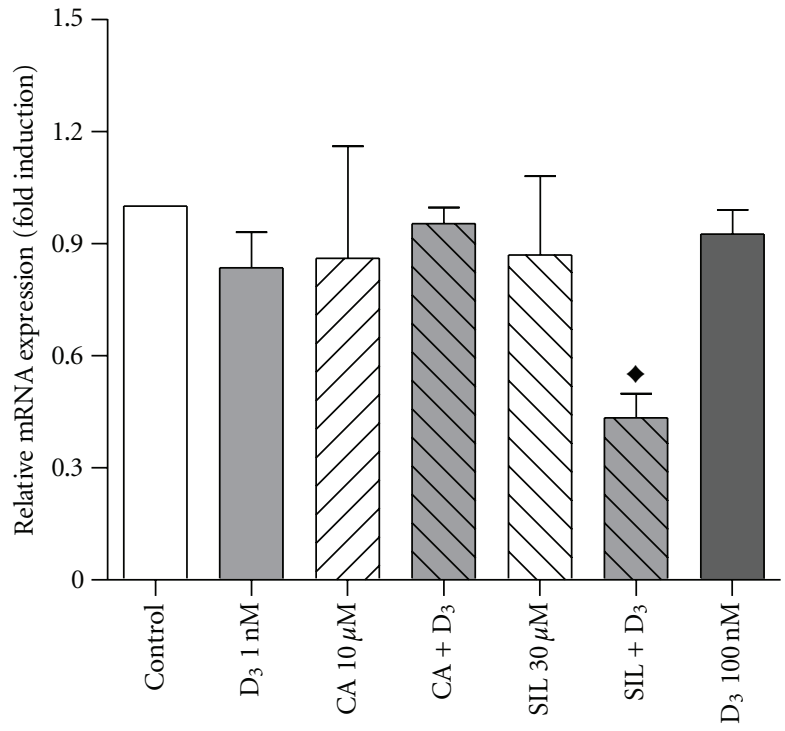

(b) U937

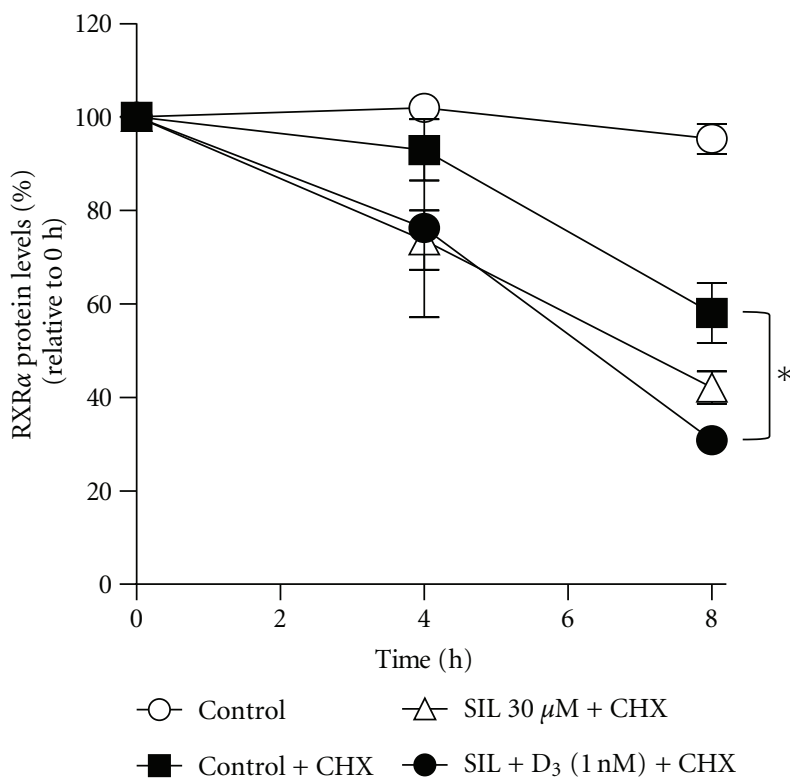

(d) U937

FIgURE 6: Silibinin promotes downregulation of RXR $\alpha$ in U937 cells but not in HL60 cells. (a), (b) HL60 and U937 cells (5 × $10^{4}$ cells/mL) were treated with $0.1 \%$ ethanol (control) or the indicated test agents, for $24 \mathrm{~h}$. RXR $\alpha$ mRNA expression was determined by quantitative RT-PCR. The data are the means \pm SE of 3 independent experiments performed in duplicate $\bullet P<0.05$, combination versus control.(c) U937 cells $\left(5 \times 10^{4}\right.$ cells $\left./ \mathrm{mL}\right)$ were preincubated for $72 \mathrm{~h}$ with $0.1 \%$ ethanol (lanes $\left.1-6\right)$, silibinin alone (lanes $7-9$ ), or in combination with 1,25D (lanes 10-12) followed by treatment with vehicle $\left(\mathrm{H}_{2} \mathrm{O}\right.$, lanes 1-3) or cycloheximide (CHX, lanes 4-12) for 0-8 h, as indicated. Cells were then lysed and protein levels were determined by Western blotting. Calreticulin (CRN) was used as the protein loading control. Representative blots of 3 independent experiments are shown. (d) Graphical representation of changes in RXR $\alpha$ protein levels (determined as shown in panel (c)) relative to $0 \mathrm{~h}$ (lanes $1,4,7,10$, resp., for corresponding treatments); means $\pm \mathrm{SE} ; n=3$. $P<0.05$.

a few transcription factors, for example, lymphoblasticleukemia-derived sequence 1 (LYL1) [47] and homeobox B6 (HOXB6) [48], were associated with inhibition of monocytic differentiation of myeloid precursors. Although it was found that ERK5 does not directly phosphorylate RXR $\alpha$ in response to $1,25 \mathrm{D}$ [49], the relationship between the other negative regulators of monocytic differentiation and RXR $\alpha$ expression or function remains to be elucidated. Since Nrf2 may function as a positive regulator of RXR $\alpha$ expression [11], the failure of SIL to stimulate the Nrf2/ARE in U937 cells may contribute to its negative effect on $\operatorname{RXR} \alpha$ levels and, thereby, on 1,25D-induced differentiation of these cells. The reason why, in contrast to CA, SIL can activate Nrf2/ARE in HL60 cells but not in U937 cells is unclear and may be related to 
possible differences in the metabolic fate of SIL in the two cell types.

In conclusion, our results demonstrate that the contrasting effects of SIL on the differentiation of myeloblastic (HL60) and promonocytic (U937) AML cells are related, at least in part, to its opposing modulation of the VDR signaling pathway. We suggest that U937 cells may present a model for patient-derived leukemic blasts which respond to SIL $[16,17]$ and similarly acting compounds by inhibition of $1,25 \mathrm{D}$-induced differentiation. SIL has been shown to inhibit proliferation of various types of cancer cells (see $[50,51]$ for recent reviews). Likewise, this polyphenol demonstrated a marked antiproliferative activity in both AML cell lines tested here, even though it negatively affected the differentiation of U937 cells. Therefore, further preclinical studies are required to determine the potential use of different plant polyphenols for AML treatment and/or prevention.

\section{Acknowledgments}

The authors thank Dr. Andrzej Kutner for the gift of 1,25D. This research was supported by the Israel Science Foundation grant 635/11.

\section{References}

[1] A. Redaelli, M. F. Botteman, J. M. Stephens, S. Brandt, and C. L. Pashos, "Economic burden of acute myeloid leukemia: a literature review," Cancer Treatment Reviews, vol. 30, no. 3, pp. 237-247, 2004.

[2] J. L. Shipley and J. N. Butera, "Acute myelogenous leukemia," Experimental Hematology, vol. 37, no. 6, pp. 649-658, 2009.

[3] A. T. Fathi, S. Grant, and J. E. Karp, "Exploiting cellular pathways to develop new treatment strategies for AML," Cancer Treatment Reviews, vol. 36, no. 2, pp. 142-150, 2010.

[4] P. J. Hughes, E. Marcinkowska, E. Gocek, G. P. Studzinski, and G. Brown, "Vitamin $\mathrm{D}_{3}$-driven signals for myeloid cell differentiation-implications for differentiation therapy," Leukemia Research, vol. 34, no. 5, pp. 553-565, 2010.

[5] G. Jones, "Vitamin D analogs," Endocrinology and Metabolism Clinics of North America, vol. 39, no. 2, pp. 447-472, 2010.

[6] M. Danilenko and G. P. Studzinski, "Enhancement by other compounds of the anti-cancer activity of vitamin $\mathrm{D}_{3}$ and its analogs," Experimental Cell Research, vol. 298, no. 2, pp. 339358, 2004.

[7] M. Danilenko, Q. Wang, X. Wang, J. Levy, Y. Sharoni, and G. P. Studzinski, "Carnosic acid potentiates the antioxidant and prodifferentiation effects of $1 \alpha, 25$-dihydroxyvitamin $\mathrm{D}_{3}$ in leukemia cells but does not promote elevation of basal levels of intracellular calcium," Cancer Research, vol. 63, no. 6, pp. 1325-1332, 2003.

[8] M. Danilenko, X. Wang, and G. P. Studzinski, "Carnosic acid and promotion of monocytic differentiation of HL60-G cells initiated by other agents," Journal of the National Cancer Institute, vol. 93, no. 16, pp. 1224-1233, 2001.

[9] M. Steiner, I. Priel, J. Giat, J. Levy, Y. Sharoni, and M. Danilenko, "Carnosic acid inhibits proliferation and augments differentiation of human leukemic cells induced by 1,25 -dihydroxyvitamin $\mathrm{D}_{3}$ and retinoic acid," Nutrition and Cancer, vol. 41, no. 1-2, pp. 135-144, 2001.
[10] J. Zhang, G. H. Posner, M. Danilenko, and G. P. Studzinski, "Differentiation-inducing potency of the seco-steroid JK$1624 \mathrm{~F} 2-2$ can be increased by combination with an antioxidant and a p38MAPK inhibitor which upregulates the JNK pathway," Journal of Steroid Biochemistry and Molecular Biology, vol. 105, no. 1-5, pp. 140-149, 2007.

[11] I. Bobilev, V. Novik, I. Levi et al., "The Nrf2 transcription factor is a positive regulator of myeloid differentiation of acute myeloid leukemia cells," Cancer Biology and Therapy, vol. 11, no. 3, pp. 317-329, 2011.

[12] T. Thompson, M. Danilenko, L. Vassilev, and G. P. Studzinski, "Tumor suppressor p53 status does not determine the differentiation- associated $\mathrm{G}_{1}$ cell cycle arrest induced in leukemia cells by 1,25-dihydroxyvitamin $\mathrm{D}_{3}$ and antioxidants," Cancer Biology and Therapy, vol. 10, no. 4, pp. 344-350, 2010.

[13] H. Sharabani, E. Izumchenko, Q. Wang et al., "Cooperative antitumor effects of vitamin $\mathrm{D}_{3}$ derivatives and rosemary preparations in a mouse model of myeloid leukemia," International Journal of Cancer, vol. 118, no. 12, pp. 3012-3021, 2006.

[14] A. Shabtay, H. Sharabani, Z. Barvish et al., "Synergistic antileukemic activity of carnosic acid-rich rosemary extract and the 19-nor Gemini vitamin D analogue in a mouse model of systemic acute myeloid leukemia," Oncology, vol. 75, no. 34, pp. 203-214, 2008.

[15] S. N. Kang, M. H. Lee, K. M. Kim, D. Cho, and T. S. Kim, "Induction of human promyelocytic leukemia HL-60 cell differentiation into monocytes by silibinin: involvement of protein kinase C," Biochemical Pharmacology, vol. 61, no. 12, pp. 1487-1495, 2001.

[16] X. Wang, E. Gocek, V. Novik, J. S. Harrison, M. Danilenko, and G. P. Studzinski, "Inhibition of Cot1/Tlp2 oncogene in AML cells reduces ERK5 activation and upregulates p27Kip1 concomitant with enhancement of differentiation and cell cycle arrest induced by silibinin and 1,25-dihydroxyvitamin D 3 ," Cell Cycle, vol. 9, no. 22, pp. 4542-4551, 2010.

[17] J. Zhang, J. S. Harrison, M. Uskokovic, M. Danilenko, and G. P. Studzinski, "Silibinin can induce differentiation as well as enhance vitamin $\mathrm{D}_{3}$-induced differentiation of human AML cells ex vivo and regulates the levels of differentiation-related transcription factors," Hematological Oncology, vol. 28, no. 3, pp. 124-132, 2010.

[18] S. B. Cullinan, D. Zhang, M. Hannink, E. Arvisais, R. J. Kaufman, and J. A. Diehl, "Nrf2 is a direct PERK substrate and effector of PERK-dependent cell survival," Molecular and Cellular Biology, vol. 23, no. 20, pp. 7198-7209, 2003.

[19] G. P. Studzinski, K. B. Reddy, H. Z. Hill, and A. K. Bhandal, "Potentiation of $1-\beta$-D-arabinofuranosylcytosine cytotoxicity to HL-60 cells by 1,25 -dihydroxyvitamin $\mathrm{D}_{3}$ correlates with reduced rate of maturation of DNA replication intermediates," Cancer Research, vol. 51, no. 13, pp. 3451-3455, 1991.

[20] Q. Wang, H. Salman, M. Danilenko, and G. P. Studzinski, "Cooperation between antioxidants and 1,25-dihydroxyvitamin $\mathrm{D}_{3}$ in induction of leukemia HL60 cell differentiation through the JNK/AP-1/Egr-1 pathway," Journal of Cellular Physiology, vol. 204, no. 3, pp. 964-974, 2005.

[21] S. Pesakhov, M. Khanin, G. P. Studzinski, and M. Danilenko, "Distinct combinatorial effects of the plant polyphenols curcumin, carnosic acid, and silibinin on proliferation and apoptosis in acute myeloid leukemia cells," Nutrition and Cancer, vol. 62, no. 6, pp. 811-824, 2010.

[22] A. Dimberg, F. Bahram, I. Karlberg, L. G. Larsson, K. Nilsson, and F. Öberg, "Retinoic acid-induced cell cycle arrest of human myeloid cell lines is associated with sequential downregulation of $\mathrm{c}-\mathrm{Myc}$ and cyclin $\mathrm{E}$ and posttranscriptional 
up-regulation of p27 ${ }^{\text {Kipl } 1, ~ B l o o d, ~ v o l . ~ 99, ~ n o . ~ 6, ~ p p . ~ 2199-2206, ~}$ 2002.

[23] M. K. Kwak and T. W. Kensler, "Targeting NRF2 signaling for cancer chemoprevention," Toxicology and Applied Pharmacology, vol. 244, no. 1, pp. 66-76, 2010.

[24] J. A. Sokoloski, K. Shyam, and A. C. Sartorelli, "Induction of the differentiation of hl-60 promyelocytic leukemia cells by curcumin in combination with low levels of vitamin $\mathrm{D}_{3}$," Oncology Research, vol. 9, no. 1, pp. 31-39, 1997.

[25] Y. Liu, R. L. Chang, X. X. Cui, H. L. Newmark, and A. H. Conney, "Synergistic effects of curcumin on all-trans retinoic acid-and $1 \alpha, 25$-dihydroxyvitamin $\mathrm{D}_{3}$-induced differentiation in human promyelocytic leukemia HL-60 cells," Oncology Research, vol. 9, no. 1, pp. 19-29, 1997.

[26] K. H. Poon, J. Zhang, C. Wang, A. K. Tse, C. K. Wan, and W. F. Fong, "Betulinic acid enhances $1 \alpha, 25$-dihydroxyvitamin $\mathrm{D}_{3}$-induced differentiation in human HL-60 promyelocytic leukemia cells," Anti-Cancer Drugs, vol. 15, no. 6, pp. 619-624, 2004.

[27] S. N. Kang, S. H. Kim, S. W. Chung, M. H. Lee, H. J. Kim, and T. S. Kim, "Enhancement of $1 \alpha, 25$-dihydroxyvitamin $\mathrm{D}_{3}$ induced differentiation of human leukaemia HL-60 cells into monocytes by parthenolide via inhibition of NF- $\kappa$ B activity," British Journal of Pharmacology, vol. 135, no. 5, pp. 1235-1244, 2002.

[28] S. H. Kim, S. N. Kang, H. J. Kim, and T. S. Kim, "Potentiation of 1,25-dihydroxyvitamin $\mathrm{D}_{3}$-induced differentiation of human promyelocytic leukemia cells into monocytes by costunolide, a germacranolide sesquiterpene lactone," Biochemical Pharmacology, vol. 64, no. 8, pp. 1233-1242, 2002.

[29] S. H. Kim, H. J. Kim, and T. S. Kim, "Differential involvement of protein kinase $\mathrm{C}$ in human promyelocytic leukemia cell differentiation enhanced by artemisinin," European Journal of Pharmacology, vol. 482, no. 1-3, pp. 67-76, 2003.

[30] J. A. Sokoloski, W. F. Hodnick, S. T. Mayne, C. Cinquina, C. S. Kim, and A. C. Sartorelli, "Induction of the differentiation of HL-60 promyelocytic leukemia cells by vitamin E and other antioxidants in combination with low levels of vitamin $\mathrm{D}_{3}$ : possible relationship to NF- $\kappa \mathrm{B}$," Leukemia, vol. 11, no. 9, pp. 1546-1553, 1997.

[31] H. Amir, M. Karas, J. Giat et al., "Lycopene and 1,25dihydroxyvitamin $\mathrm{D}_{3}$ cooperate in the inhibition of cell cycle progression and induction of differentiation in HL-60 leukemic cells," Nutrition and Cancer, vol. 33, no. 1, pp. 105112, 1999.

[32] M. Makishima, Y. Honma, M. Hozumi et al., "Effects of inhibitors of protein tyrosine kinase activity and/or phosphatidylinositol turnover on differentiation of some human myelomonocytic leukemia cells," Leukemia Research, vol. 15, no. 8, pp. 701-708, 1991.

[33] S. N. Kang, S. W. Chung, and T. S. Kim, "Capsaicin potentiates 1,25-dihydoxyvitamin $\mathrm{D}_{3}$ and all-trans retinoic acid-induced differentiation of human promyelocytic leukemia HL-60 cells," European Journal of Pharmacology, vol. 420, no. 2-3, pp. 83-90, 2001.

[34] K. Yamada, Y. Honma, K. I. Asahi, T. Sassa, K. I. Hino, and S. Tomoyasu, "Differentiation of human acute myeloid leukaemia cells in primary culture in response to cotylenin A, a plant growth regulator," British Journal of Haematology, vol. 114, no. 4, pp. 814-821, 2001.

[35] P. K. Farmer, X. He, M. L. Schmitz, J. Rubin, and M. S. Nanes, "Inhibitory effect of NF- $\kappa$ B on 1,25-dihydroxyvitamin $\mathrm{D}_{3}$ and retinoid X receptor function," American Journal of
Physiology-Endocrinology and Metabolism, vol. 269, no. 1, pp. E213-E220, 2000.

[36] X. Lu, P. Farmer, J. Rubin, and M. S. Nanes, "Integration of the $\mathrm{Nf} \kappa \mathrm{B}$ p65 subunit into the vitamin D receptor transcriptional complex: identification of p65 domains that inhibit 1,25dihydroxyvitamin $\mathrm{D}_{3}$-stimulated transcription," Journal of Cellular Biochemistry, vol. 92, no. 4, pp. 833-848, 2004.

[37] X. Qi, R. Pramanik, J. Wang et al., “The p38 and JNK pathways cooperate to trans-activate vitamin D receptor via c-Jun/AP-1 and sensitize human breast cancer cells to vitamin $\mathrm{D}_{3}$-induced growth inhibition," The Journal of Biological Chemistry, vol. 277, no. 29, pp. 25884-25892, 2002.

[38] A. Takeshita, A. Watanabe, Y. Takada, and S. Hanazawa, "Selective stimulation by ceramide of the expression of the $\alpha$ isoform of retinoic acid and retinoid $\mathrm{X}$ receptors in osteoblastic cells. A role of sphingosine 1-phosphate-mediated AP-1 in the ligand-dependent transcriptional activity of these receptors," The Journal of Biological Chemistry, vol. 275, no. 41, pp. 32220-32226, 2000.

[39] J. Li, R. A. Finch, and A. C. Sartorelli, "Role of vitamin $\mathrm{D}_{3}$ receptor in the synergistic differentiation of WEHI- 3B leukemia cells by vitamin $\mathrm{D}_{3}$ and retinoic acid," Experimental Cell Research, vol. 249, no. 2, pp. 279-290, 1999.

[40] Y. Amano, Y. Cho, M. Matsunawa, K. Komiyama, and M. Makishima, "Increased nuclear expression and transactivation of vitamin D receptor by the cardiotonic steroid bufalin in human myeloid leukemia cells," Journal of Steroid Biochemistry and Molecular Biology, vol. 114, no. 3-5, pp. 144-151, 2009.

[41] S. Swami, A. V. Krishnan, D. M. Peehl, and D. Feldman, "Genistein potentiates the growth inhibitory effects of 1,25dihydroxyvitamin $\mathrm{D}_{3}$ in DU145 human prostate cancer cells: role of the direct inhibition of CYP24 enzyme activity," Molecular and Cellular Endocrinology, vol. 241, no. 1-2, pp. 4961, 2005.

[42] J. A. Wietzke and J. Welsh, "Phytoestrogen regulation of a Vitamin $\mathrm{D}_{3}$ receptor promoter and 1,25-dihydroxyvitamin $\mathrm{D}_{3}$ actions in human breast cancer cells," Journal of Steroid Biochemistry and Molecular Biology, vol. 84, no. 2-3, pp. 149157, 2003.

[43] L. A. Gilad, O. Tirosh, and B. Schwartz, "Phytoestrogen regulate transcription and translation of vitamin $\mathrm{D}$ receptor in colon cancer cells," Journal of Endocrinology, vol. 191, no. 2, pp. 387-398, 2006.

[44] Y. Yin, J. Ni, M. Chen, Y. Guo, and S. Yeh, "RRR- $\alpha$-vitamin E succinate potentiates the antitumor effect of calcitriol in prostate cancer without overt side effects," Clinical Cancer Research, vol. 15, no. 1, pp. 190-200, 2009.

[45] S. Álvarez, W. Bourguet, H. Gronemeyer, and A. R. de Lera, "Retinoic acid receptor modulators: a perspective on recent advances and promises," Expert Opinion on Therapeutic Patents, vol. 21, no. 1, pp. 55-63, 2011.

[46] X. Wang and G. P. Studzinski, "Expression of MAP3 kinase COT1 is up-regulated by 1,25-dihydroxyvitamin $\mathrm{D}_{3}$ in parallel with activated c-jun during differentiation of human myeloid leukemia cells," Journal of Steroid Biochemistry and Molecular Biology, vol. 121, no. 1-2, pp. 395-398, 2010.

[47] Y. S. Meng, H. Khoury, J. E. Dick, and M. D. Minden, "Oncogenic potential of the transcription factor LYL1 in acute myeloblastic leukemia," Leukemia, vol. 19, no. 11, pp. 19411947, 2005.

[48] A. Giampaolo, N. Felli, D. Diverio et al., "Expression pattern of HOXB6 homeobox gene in myelomonocytic differentiation and acute myeloid leukemia," Leukemia, vol. 16, no. 7, pp. 1293-1301, 2002. 
[49] P. P. Dwivedi, C. S. Hii, A. Ferrante et al., "Role of MAP kinases in the 1,25-dihydroxyvitamin $\mathrm{D}_{3}$-induced transactivation of the rat cytochrome P450c24 (CYP24) promoter: specific functions for ERK1/ERK2 and ERK5," The Journal of Biological Chemistry, vol. 277, no. 33, pp. 29643-29653, 2002.

[50] C. W. Cheung, N. Gibbons, D. W. Johnson, and D. L. Nicol, "Silibinin-a promising new treatment for cancer," Anti-Cancer Agents in Medicinal Chemistry, vol. 10, no. 3, pp. 186-195, 2010.

[51] G. Deep and R. Agarwal, "Antimetastatic efficacy of silibinin: molecular mechanisms and therapeutic potential against cancer," Cancer and Metastasis Reviews, vol. 29, no. 3, pp. 447-463, 2010. 


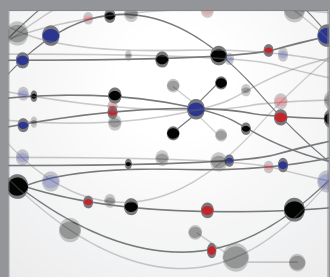

The Scientific World Journal
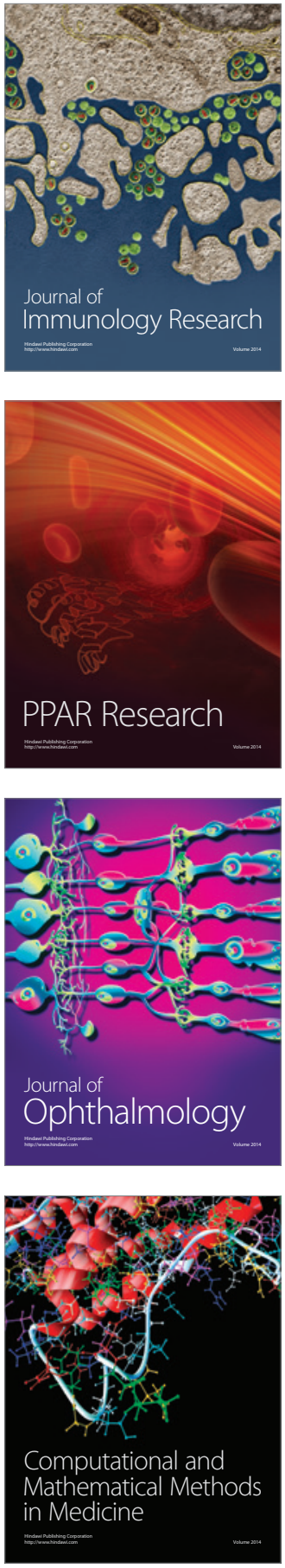

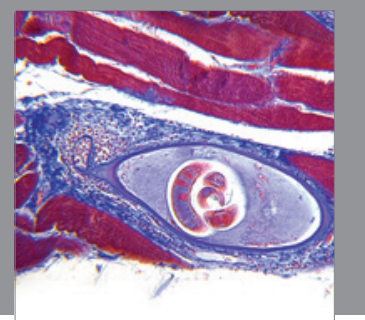

Gastroenterology

Research and Practice
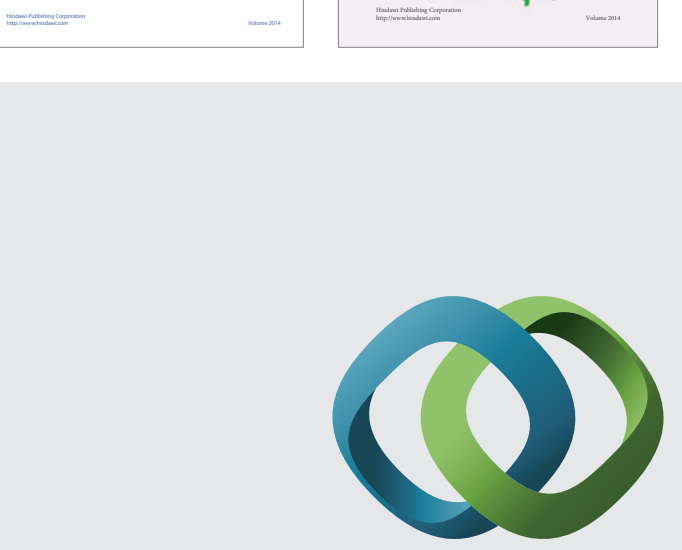

\section{Hindawi}

Submit your manuscripts at

http://www.hindawi.com
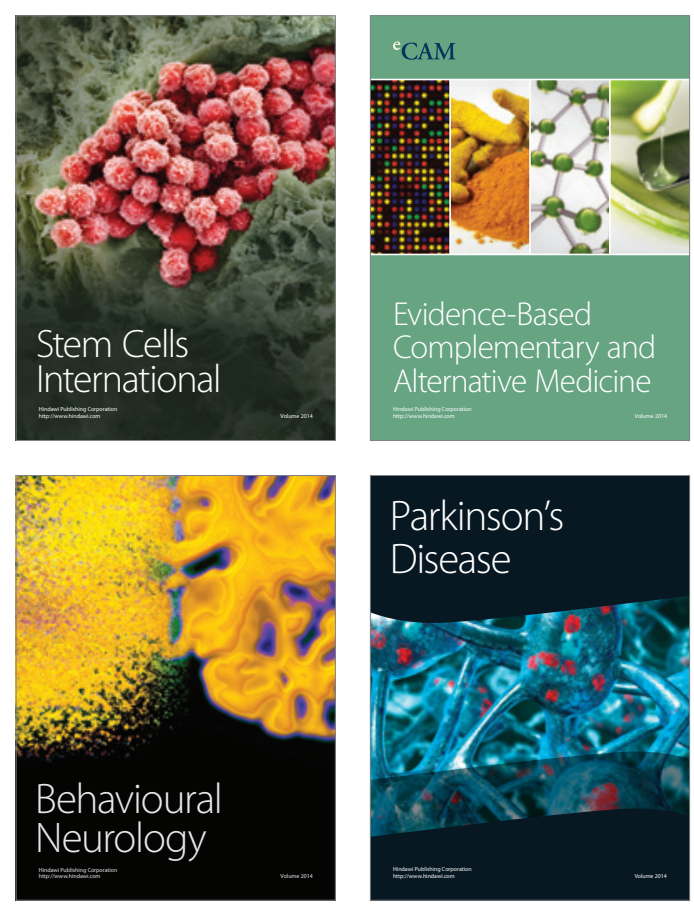

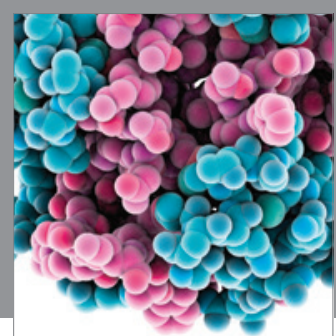

Journal of
Diabetes Research

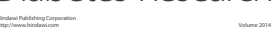

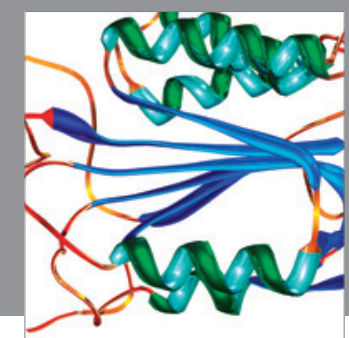

Disease Markers
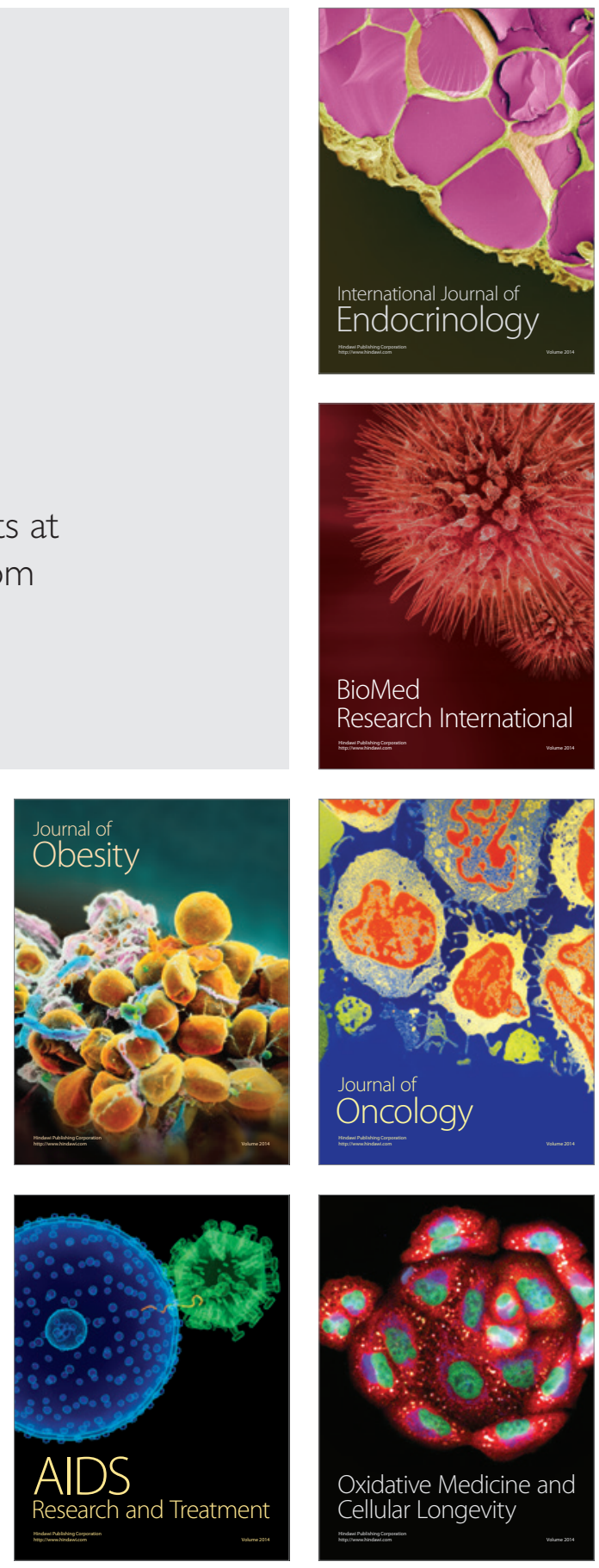